\title{
KENDALA PADA PENDEDERAN BENIH IKAN BERONANG LADA (Siganus canaliculatus) PADA KERAMBA JARING APUNG DI PERAIRAN PULAU SIRAI, TANJUNGPINANG
}

\author{
Philip Teguh Imanto dan Made Suastika \\ Balai Besar Riset Perikanan Budidaya Laut \\ Jl. Br. Gondol Kec. Gerogkak Kab. Buleleng, Kotak Pos 140, Singaraja, Bali \\ E-mail: philip_imanto@yahoo.co.id
}

\section{ABSTRAK}

Beronang lada (Siganus canaliculatus) adalah kelompok ikan yang banyak ditemukan di perairan pantai dan rataan terumbu karang, memiliki nilai ekonomis yang cukup tinggi terutama pada saat hari raya Imlek, di mana ikan yang matang gonad sangat digemari dan mencapai harga tertinggi hingga Rp 110 ribu/kg. Hal ini menarik minat pembudidaya untuk memelihara dan membesarkan dengan tujuan mencapai ukuran matang gonad pada saat tersebut. Ketersediaan benih yang melimpah dan mudah diperoleh menyebabkan pengusaha memelihara dengan kepadatan tinggi hingga 5 ribu ekor per kurungan berukuran $3 \mathrm{mx}$ $3 \mathrm{~m} \times 2 \mathrm{~m}\left(18 \mathrm{~m}^{3}\right)$, dengan sediaan pakan potongan padang lamun dan pelet kakap ko mersial seri KPA 3-4. Kendala kematian benih yang cukup tinggi muncul pada saat pemeliharaan, yang dicirikan dengan gerakan abnormal, mulut kemerahan, dan ekor yang terkikis. Pengamatan lapang dilakukan pada fasilitas pemeliharaan dan wawancara untuk mendapat gambaran umum kondisi budidaya, serta pengambilan sampel benih sehat dan yang bermasalah untuk observasi visual (organoleptik) maupun secara mikroskopik. Hasil pengamatan dengan miksroskop diketahui mulut yang memerah disebabkan kerusakan pada gigi dan bibir, serta ekor yang terkikis lebih disebabkan gigitan benih ikan yang sehat. Perbaikan manajemen budidaya disarankan dilakukan dengan mengurangi tingkat kepadatan, penggunaan pelet basah (moist pellet) serta meningkatkan frekuensi pemberian pakan diharapkan dapat membantu mengatasi permasalahan.

KATA KUNCl: beronang lada, mati massal, padat tebar, manajemen pakan

\section{PENDAHULUAN}

Ikan beronang lada (S. canaliculatus) adalah kelompok ikan yang hidup di wilayah pantai dengan padang lamun (seagrass) yang cukup rapat, dan dikenal sebagai ikan herbivora. Anonimus (2007) menyatakan bahwa ikan beronang seperti umumnya "primary herbivor" yaitu pemakan plankton nabati tumbuhan, diketahui juga dapat memakan makanan buatan.

\section{Nilai Komersial}

Ikan beronang lada memiliki nilai ekonomi yang unik dan spesifik, pada sekitar hari raya Imlek (sehari sebelum dan sesudahnya) harganya kisaran Rp 80-110 ribu/kg, sebab pada saat itu merupakan makanan khusus dan disebut 'Pei Tor' yang bagi bangsa Cina diyakini membawa keberuntungan (Anonimus, 2009). Setelah masa itu harga akan kembali stabil pada kisaran harga Rp 8-12 ribu/kg. Memperhatikan hal tersebut sangat menarik untuk mengupayakan budidaya pembesarannya dengan memperhitungkan waktu panen pada hari raya tersebut, terutama bila mencapai tingkat matang gonad (dengan kandungan gonad besar). Kegiatan budidaya pembesaran ikan ini sangat memungkinkan di perairan Kepulauan Riau disebabkan karena benih ikan ini sangat berlimpah di perairan pantai berpadang lamun, sehingga merupakan peluang untuk mendapatkan nilai tambah yang optimal.

Kegiatan penelitian untuk budidaya beronang sudah lama telah dilakukan di antaranya oleh Madeali (1985) tentang aspek biologi dan menemukan kematangan gonad beronang lada pada panjang total $198 \mathrm{~cm}$. Tanaka \& Basyarie (1982) mengenai masalah penyakit, Basyarie (1988) tentang sumberdaya biologi dan budidayanya, serta Basyari \& Tanaka (1988) yang mempelajari pemeliharaan ikan beronang dengan pakan buatan. Ismail \& Soeharmoko (1989) membuktikan bahwa beronang lada/lingkis (S. canaliculatus) memiliki pertumbuhan yang lebih cepat dibanding beronang lebas/lébam (S. javus). 


\section{Upaya Budidaya}

Beberapa pengusaha budidaya ikan laut telah merintis upaya pembesaran beronang lada (S. canaliculatus) dengan teknologi keramba jaring apung dengan pakan pelet ikan laut. Benih dikumpulkan dengan metode bagan tancap di perairan pantai berpadang lamun pada malam hari, dan kemudian benih yang berukuran 2-2,5 cm ditempatkan pada kurungan hapa (4 mm meshnet) pada fasilitas KJA, dan ke dalam media pemeliharaan diberi potonganpotongan padang lamun sebagai sumber pakan alamiah dan pelet kakap (KPA 3-4) sebagai sumber pakan utama.

\section{Kendala}

Kendala yang muncul adalah selalu terjadinya kematian massal dengan ciri-ciri mulut memerah, gerak renang berputar-putar tidak normal dan ekor nampak luka terkikis seperti dimakan parasit.

Untuk mencoba membantu meningkatkan keberhasilan kegiatan budidaya pembesaran ikan beronang lada (S. canaliculatus) dilakukan observasi langsung ke lokasi kegiatan pembesaran, dan untuk memahami permasalahan tersebut dilakukan pengamatan secara morfologis, sifat makan, maupun mikroscopik fotografi.

\section{METODE ANALISIS}

Metode observasi dilakukan untuk menganalisis penyebab kendala tersebut dilakukan di tempat pemeliharaan KJA Pulau Sirai Kepulauan Riau pada bulan Juli 2009 dengan tahapan:

1. Pengamatan lapang untuk monitoring langsung ke tempat wadah pemeliharaan melihat sifat makan benihbenih tersebut pada pakan yang disediakan, disertai wawancara dengan pelaku usahamaupun pengumpul benih.
2. Pengambilan sampel benih yang sedang dipelihara dan bermasalah, serta koleksi sampel benih ikan yang baru tertangkap, dengan tujuan untuk diamati secara mikroscopik dan dilakukan pendokumentasian.

Analisis dilakukan deskriptif dengan mencari hubungan antara tingkah laku sifat makan benih ikan beronang lada (S. canaliculatus) pada kondisi budidaya, jenis pakan serta penampilan morfologis benih yang sehat (baru tertangkap) dan benih yang mengalami masalah (mulut merah, ekor terkikis, dan gerak renang abnormal).

Alat yang digunakan dalam observasi ini meliputi portable digital microscopic camera, stereoscopic microscope, petridisk, dan alat bedah (dissecting set), dengan dibantu perangkat lunak ulead photo explorer 7.0 untuk dokumentasi digital, microsoft photo editor, dan MGI Photosuite untuk pengolahan gambar, serta microsoft word untuk penyusunan laporan.

\section{HASIL DAN BAHASAN}

Hasil pengamatan diuraikan secara bertahap mulai dari sarana pengumpulan benih, sarana pendederan/ pembesaran benih ikan beronang lada (S. canaliculatus), gambaran umum gerak renang dan sifat makan benih ikan dalam sarana pendederan/pembesaran, detil morfologi bagian badan ikan yang bermasalah dan yang normal, dan analisis permasalahan dengan menghubungkan setiap kejadian.

Sarana pengumpulan benih ikan beronang lada (S. canaliculatus) menggunakan bagan tancap yang berada pada kawasan pantai berpadang lamun, dan biasanya dilakukan pada waktu malam hari dengan menggunakan cahaya seperti pada ilustrasi Gambar 1.

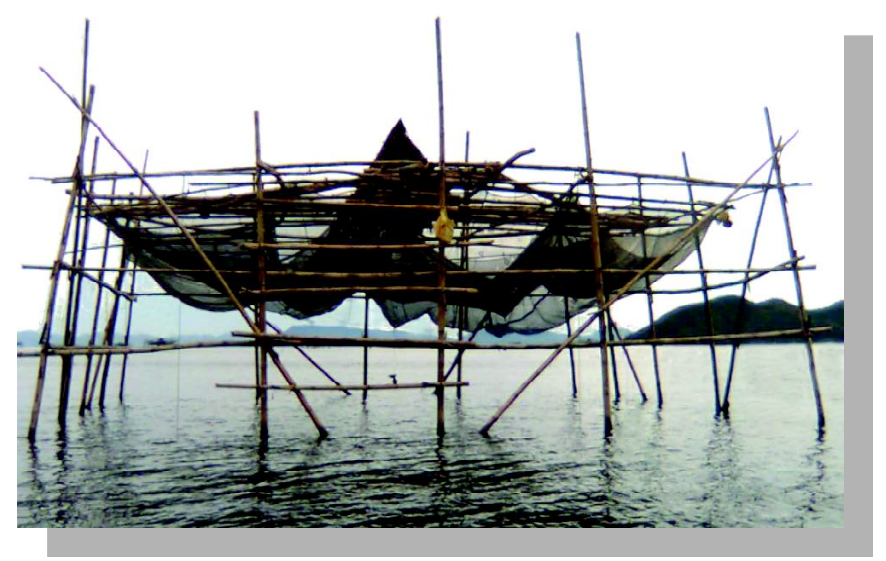

Sumber gambar bagan tancap:

http://dkpacehsingkil.org/admin/imgcontent/gal eri/1211916113.jpg

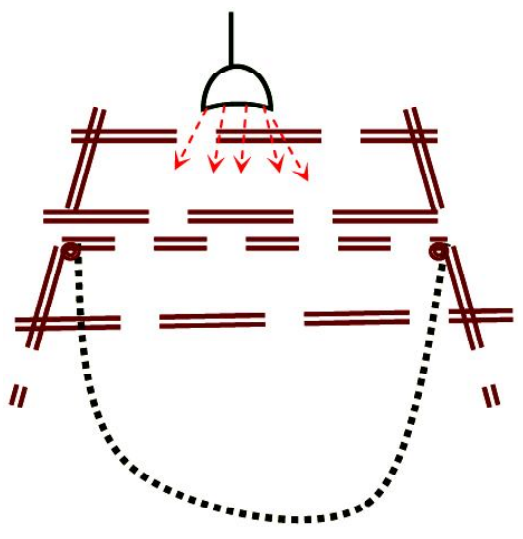

II

Gambar 1. Penggunaan cahaya pada bagan tancap 
Benih ikan yang terkumpul ditempatkan pada palka bersirkulasi, untuk ditransportasikan ke lokasi pendederan/pembesaran. Dari wawancara yang didapat dari nelayan pengumpul diperoleh angka pengumpulan benih dengan kisaran 3-10 ribu ekor setiap hari penangkapan (biasanya pada saat surut bulan baru/gelap), ukuran benih berkisar $2-3 \mathrm{~cm}$. Hal ini sesuai dengan yang diungkapkan oleh Woodland (1990) benih beronang lada (Gambar 2) berkelompok sangat banyak (very large schools) pada perairan dangkal dan rataan terumbu karang.

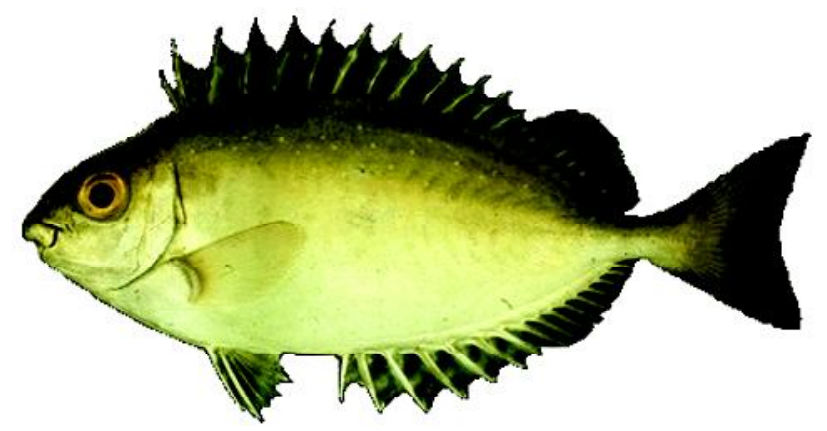

Gambar 2. Benih beronang lada (S. canaliculatus)

Sarana pendederan/pembesaran benih beronang lada (S. canaliculatus) menggunakan jaring hapa (PE net) dengan meshnet $4 \mathrm{~mm}$, ukuran kurungan adalah $3 \mathrm{~m} \times 3$ $m \times 2$ m (Gambar 3), padat penebaran setiap kurungan berkisar 5 ribu ekor dengan sediaan pakan berupa potongan padang lamun (berkisar 6-10 rumpun setiap 2 hari) dan pelet ikan laut KPA 3-4 (tipe apung) rata-rata 2 $\mathrm{kg} /$ hari.

Padat penebaran yang tinggi ini dapat dipahami oleh karena mudahnya mendapatkan benih dan masih sangat murah ( $<50$,-lekor), yang menyebabkan pengusaha berani mencoba membudidayakannya secara massal.

Pola berenang dan sifat makan benih ikan beronang lada (S. canaliculatus) pada pemeliharaan dalam kurungan hapa dapat di ilustrasikan pada gambar 4.

Pada saat pemberian pakan dengan pelet KPA 3-4, benih ikan cenderung menyerbu secara bergerombol dan berebut untuk mencoba mengambil makanan dan nampak seperti berbuih karena bernafsunya untuk menggigit pelet yang keras.

Anonimus (2007) mengungkapkan tentang morfologi dari gigi dan saluran pencernaannya yaitu mulutnya kecil, mempunyai gigi seri pada masing-masing rahang, gigi geraham berkembang sempurna, dinding lambung agak tebal, usus halusnya panjang, dan mempunyai permukaan yang luas, ikan beronang termasuk pemakan tumbuhtumbuhan, tetapi kalau dibudidayakan ikan beronang mampu memakan makanan apa saja yang diberikan seperti pakan buatan.
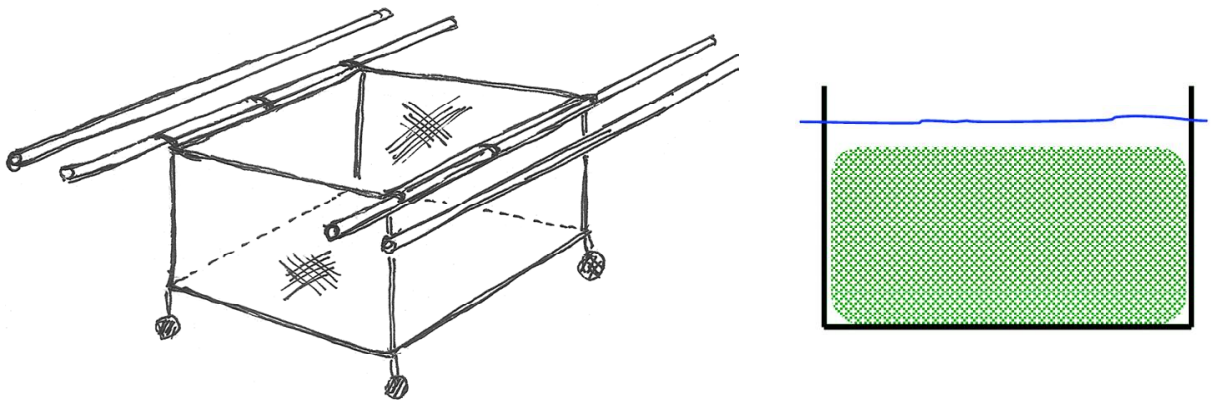

Gambar 3. Kurungan sarana pendederan benih beronang dengan jaring hapa
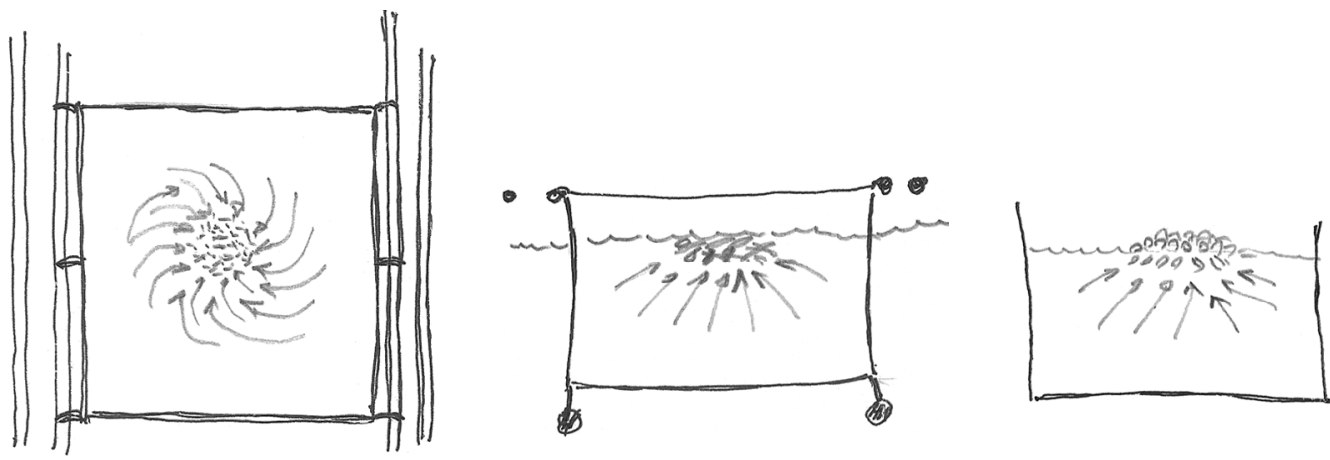

Gambar 4. Pergerakan benih beronang menyerbu pakan pelet kering 
Detil morfologi bagian mulut benih ikan yang bermasalah dan normal ditampilkan pada Gambar 5.

Dari Gambar 5 tampak dengan jelas terjadinya kerusakan gigi dari benih ikan yang bermasalah (dicirikan dengan mulut kemerahan dan bergerak abnormal) dibanding dengan benih ikan yang baru ditangkap (normal), dari foto detil morfologi bagian gigi ini jelas sekali ada perbedaan di mana pada benih alam (A) susunan gigi beraturan dan runcing serta bagian tepi mulut (bibir) yang utuh, sedang pada benih bermasalah (B) nampak dengan jelas gigi yang tidak runcing beraturan, sebagian gigi seri maupun geraham sudah tanggal dan pecah, serta bagian bibir yang mengalami iritasi (peradangan).

Pada Gambar 6 ditampilkan detil ekor benih ikan yang bermasalah, lembar sirip ekor terkikis/terluka sehingga nampak duri lunaknya, yang diduga dengan memperhatikan detilnya lebih kepada luka karena tergigit oleh benih ikan yang lain, dibanding gigitan parasit, karena jenis-jenis parasit tidak terdeteksi pada tubuh benih yang sakit.

Analisis pada hal-hal tersebut di atas dapat dijelaskan sebagai berikut: benih ikan hasil pengumpulan dengan bagan tancap tergolong benih yang sangat baik, sehat, dan responsif, dengan sifat yang membentuk suatu kelompok (schooling), tidak ditemukan adanya parasit pada insang yang dikenal sebagai monogenea trematoda seperti yang diungkapkan oleh Tanaka \& Basyarie (1982). Dari perilaku makan benih yang diilustrasikan pada Gambar 4. dapat dimengerti bahwa benih-benih beronang tersebut memiliki keinginan makan yang sangat besar (rakus) pada kondisi budidaya dengan kepadatan tinggi dan ini diduga disebabkan sumber pakan alami (macro-benthos) dari rumpun padang lamun yang disediakan tidak mencukupi. Penambahan rumpun padang lamun tidak memungkinan, karena akan mempersempit ruang gerak benih ikan, menghambat arus, dan pergantian massa air.

Padat penebaran juga diduga menjadi salah satu faktor munculnya kendala pada pemeliharaan, meskipun Burhanudin \& Sulaiman (1992) menyatakan bahwa sifat beronang yang menggerombol merupakan petunjuk jenis ikan ini mampu untuk dibudidayakan dengan kepadatan tinggi dan faktor pembatasnya adalah kelimpahan pakan alaminya.

Kondisi biologis dari benih ikan beronang lada ( $\mathrm{S}$. canaliculatus) yang masih muda $(<4 \mathrm{~cm})$, termasuk dereten gigi yang belum keras (masih agak rapuh) dan yang seharusnya digunakan untuk mengambil organisme macro benthos yang cukup lunak, dengan terpaksa digunakan untuk mencoba menggigit pelet kering KPA 4-5.

Diyakini sifat agresif benih ikan beronang yang kelaparan dan tingkat kekerasan pelet ikan yang disediakan menjadi masalah pada pemeliharaannya, yang menyebabkan pecahnya struktur gigi dan bibir bagian depan dari benih ikan (Gambar 5). serta terjadinya iritasi pada bagian mulut mengakibatkan munculnya peradangan (merah-merah). Benih yang lemah dan bergerak tidak normal menjadi mangsa bagi benih ikan yang lain terutama yang digigit adalah bagian ekornya (Gambar 6).
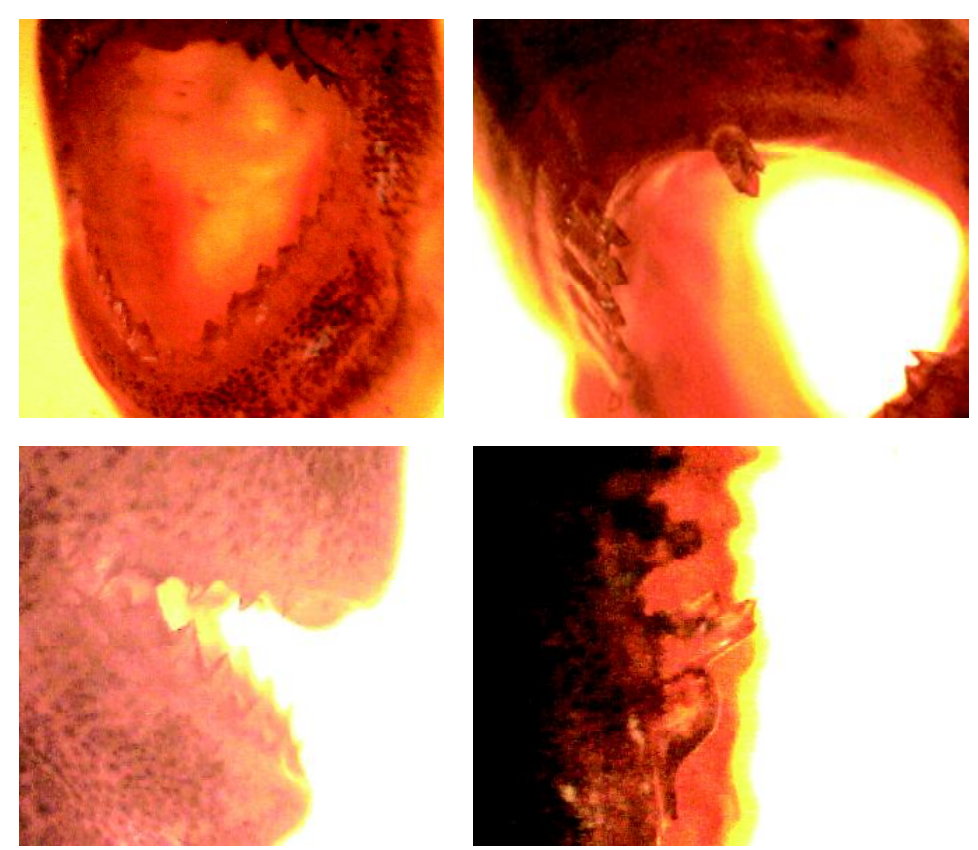

Gambar 5. Detil morfologi bagian mulut benih beronang yang sehat (A) dan yang bermasalah (B) 


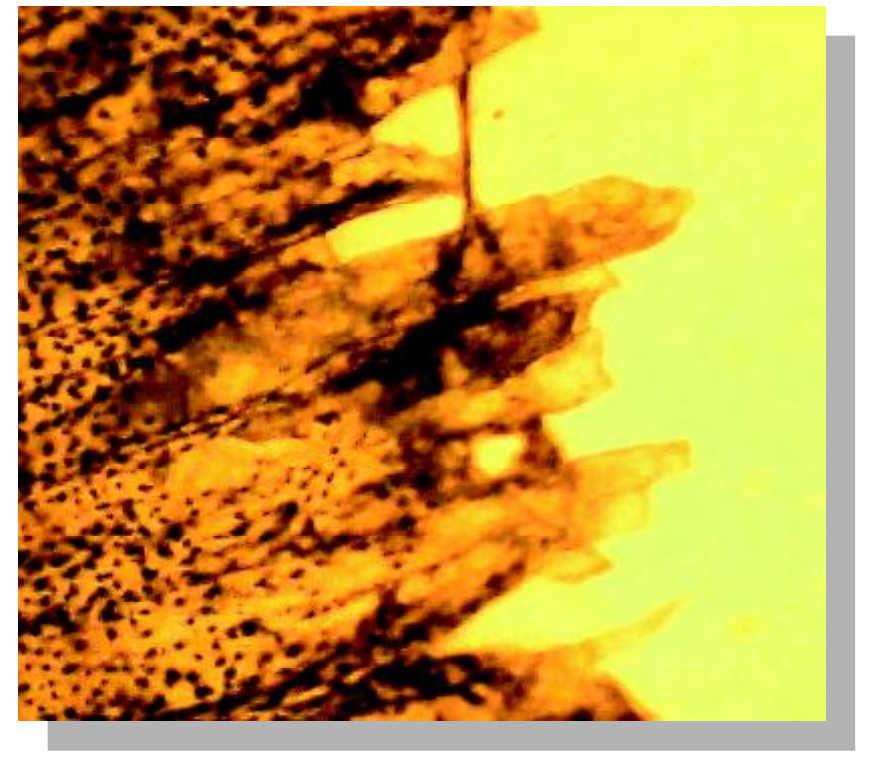

Gambar 6. Detil bagian ekor yang terluka/tidak utuh

\section{KESIMPULAN}

Penyebab terjadinya masalah pada pendederan benih beronang di KJA adalah:

1. Padat penebaranan yang tinggi dibanding ketersediaan pakan alami

2. Manajemen pemberian pakan dengan pelet ikan kakap KPA 3-4 kurang tepat untuk benih ikan beronang.

\section{SARAN}

Untuk itu disarankan:

1. Menurunkan tingkat kepadatan tebar (yang tentunya memerlukan uji coba lebih lanjut secara bertahap).

2. Merubah pola pemberian pakan untuk benih ikan beronang yang masih kecil $(<4 \mathrm{~cm})$ dengan pelet lunak (moisturre pellet), secara praktis pelet lunak/ basah dapat dibuat dengan menggiling pelet komersial dan mencampurkan daging ikan rucah segar (trash fish) sehingga menjadi satu dan dapat ditempatkan pada nampan plastik ataupun kantong jaring (Gambar 7). Penambahan daging ikan rucah segar di samping juga dapat membuat pelet menjadi lembut juga diharapkan meningkatkan kadar protein.

3. Penambahan vitamin maupun obat-obatan akan menambah daya tahan benih.

4. frekuensi pemberian pakan untuk ikan muda dapat dilakukan lebih dari $2 x$, dan dapat diberikan hingga $4 x /$ hari dengan memperhatikan pola makan benih itu sendiri.
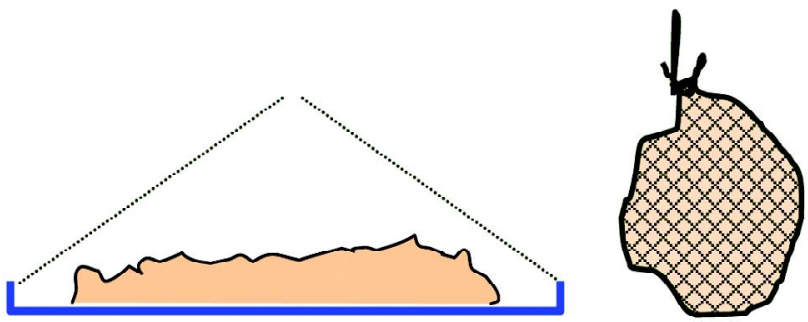

Gambar 7. Wadah pakan pelet basah/lunak

\section{UCAPAN TERIMA KASIH}

Dengan ini disampaikan terima kasih kepada Bapak Yusuf (pemilik KJA di Pulau Sirai, Tanjung Pinang Kepulauan Riau) yang memberikan kesempatan untuk mendapatkan sampel dan data di lapangan, dan semoga tulisan ini dapat dimanfaatkan untuk mencoba mengadakan perbaikan pengelolaan budidaya ikan beronang dengan lebih baik.

\section{DAFTAR ACUAN}

Anonimus. 2007. Budidaya Ikan Beronang (Siganus sp.) $11 \mathrm{hlm}$. Diakses 26 Januari 2010 dari http://www. agrina-online.com/redesign2.php? rid $=16 \&$ aid $=657$

Anonimus. 2009. White-spotted rabbitfish Siganus canaliculatus. Diakses 31 Januari 2010 dari http:// www.wildsingapore.com/wildfacts/vertebrates/fish/ siganidae/canaliculatus.htm

Basyari, A. \& Tanaka, H. 1988 Study on rearing of siganid fishes by using formula feed with different crude protein levels. In Seafarming Workshop Report, Bandar Lampung, Indonesia. Technical Report Part 2, 28 Oct. - 1 Nov. 1985, INS/81/008 /GEN/2, June 1988, p. $58-62$.

Burhanuddin \& Sulaiman. 1992. Pengaruh Padat Penebaran Terhadap Pertumbuhan Ikan Beronang, Siganusjavus Di Tambak. J. Pen. Budidaya Pantai, 8(2): 81-86

Ismail, A. \& Soehrmoko. 1989. Pengamatan Terhadap Pertumbuhan Beberapa Jenis Ikan Beronang (Siganus sp.) dalam Keramba Jaring Apung. J. Pen. Budidaya Pantai, 5(2): 66-71.

Madeali, M.I. 1985. Penelitiam Pendahuluan Beberapa Aspek Biologi Ikan Baronang Malaja (Siganus canaliculatus Park) Di Perairan Bajoe Teluk Bone, Sulawesi Selatan. J. Pen. B.P., 1(1): 55-64.

Tanaka H. \& Basyarie, A. 1982. Acute Mortality of Rabbitfish (Siganids) Caused by Monogenetic Trematodes. Bull. Pen. Perikanan, 2: 115-118.

Woodland, D.J. 1990. White-spotted spinefoot Siganus canaliculatus (Park, 1797) diakses 26 Januari 2010 dari ht t p://w w w. fishbase.us/summary/ SpeciesSummary.php?id $=4456$ 